\title{
Chaotic dynamics of a glaciohydraulic model
}

\author{
J. KINGSLAKE ${ }^{1,2}$ \\ ${ }^{1}$ British Antarctic Survey, Natural Environment Research Council, Cambridge, UK \\ ${ }^{2}$ Department of Geography, University of Sheffield, Sheffield, UK \\ Correspondence: J. Kingslake <jonngs@bas.ac.uk>
}

\begin{abstract}
A model subglacial drainage system, coupled to an ice-dammed reservoir that receives a time-varying meltwater input, is described and analysed. In numerical experiments an ice-marginal lake drains through a subglacial channel, producing periodic floods, and fills with meltwater at a rate dependent on air temperature, which varies seasonally with a peak value of $T_{\mathrm{m}}$. The analysis reveals regions of $T_{\mathrm{m}}$ parameter space corresponding to 'mode locking', where flood repeat time is independent of $T_{\mathrm{m}}$; resonance, where decreasing $T_{\mathrm{m}}$ counter-intuitively increases flood size; and chaotic dynamics, where flood cycles are sensitive to initial conditions, never repeat and exhibit phase-space mixing. Bifurcations associated with abrupt changes in flood size and timing within the year separate these regions. This is the first time these complex dynamics have been displayed by a glaciohydraulic model and these findings have implications for our understanding of ice-marginal lakes, moulins and subglacial lakes.
\end{abstract}

KEYWORDS: glacier hazards, glacier hydrology, glacier modelling, jökulhlaups (GLOFs), subglacial processes

\section{INTRODUCTION}

The filling and draining of ice-dammed reservoirs underlies many important glaciohydrological phenomena. Ice-marginal lakes fill with meltwater and can drain suddenly through subglacial channels (Nye, 1976; Björnsson, 2002; Roberts, 2005), producing subglacial floods called 'jökulhlaups' that pose hazards and impact ice dynamics (Björnsson, 2004; Anderson and others, 2005; Sugiyama and others, 2007; Bartholomaus and others 2008; Magnússon and others, 2011; Kingslake and Ng, 2013a). Englacial conduits called moulins route surface meltwater to the beds of glaciers and ice sheets, coupling ice dynamics to surface meteorological conditions (e.g. Nienow and others, 1998; Zwally and others, 2002; Bartholomew and others, 2011; Cowton and others, 2013; Schoof and others, 2014). Subglacial lakes at the beds of ice sheets reduce basal friction and influence basal conditions as they drain (e.g. Wingham and others, 2006; Bell and others, 2007; Das and others, 2008; Stearns and others, 2008; Wright and Siegert, 2012; Carter and others, 2013; Sergienko, 2013; Howat and others, 2015).

The filling and drainage of these ice-dammed reservoirs is controlled by the imbalance between two water fluxes: input controlled predominantly by meltwater production and output through a subglacial drainage system whose evolution is controlled by the water pressure in the reservoir. Hence these reservoirs are coupled to subglacial drainage systems in terms of water pressure and discharge (Nye, 1976; Ng, 1998; Flowers and others, 2004; Evatt, 2006; Kingslake and $\mathrm{Ng}, 2013 \mathrm{a}$ ).

Nye's (1976) model of an ice-dammed lake that drains through a subglacial channel to produce jökulhlaups was the first mathematical description of this coupling. It has been used to investigate various aspects of jökulhlaup dynamics (e.g. Spring and Hutter, 1981; Clarke, 1982, 2003; Björnsson, 1992, 1998; Ng, 1998; Fowler, 1999, 2009; Jóhannesson, 2002; Ng and Björnsson, 2003; Kessler and Anderson, 2004; Evatt, 2006; Ng and Liu, 2009; Pimentel and Flowers, 2011; Kingslake and Ng, 2013a; Schoof and others, 2014). In particular, Fowler (1999) showed that a modified version of Nye's (1976) model can simulate stable, periodic flood cycles when a constant water input is supplied to the lake and the subglacial channel along its length (Evatt, 2006; Kingslake and Ng, 2013a). Fowler (1999) also showed that modelled floods are larger when the constant input to the lake is larger. This is due to the dynamics of a subglacial hydraulic divide that forms during lake-filling periods and could explain observed variability in the size of floods ( $\mathrm{Ng}$ and others, 2007; Ng and Liu, 2009; Kingslake, 2013; Kingslake and Ng, 2013b).

Most previous jökulhlaup modelling studies have used a constant lake input. This is unrealistic. Real ice-dammed reservoirs receive water inputs that vary on diurnal, seasonal and interannual timescales (e.g. Bartholomaus and others 2008; Ng and Liu, 2009; Kingslake and Ng, 2013b; Schoof and others, 2014; Siegfried and others, 2014). Here we investigate the behaviour of Nye's (1976) model when it is forced with a meltwater input that depends on a seasonally varying synthetic air temperature time series. Section 2 describes the model, this seasonally varying forcing, our numerical methods and a suite of numerical simulations during which the magnitude of air temperature variations is varied between simulations. In Section 3 we present the results of these simulations and show that simulated flood cycles can be 'mode-locked', so that their repeat time equals an integer multiple of the forcing period ( 1 year), and 'resonate' when forced with air temperature variations of particular magnitudes. We also show that the model can behave chaotically, where simulated time series are highly sensitive to initial conditions and never repeat exactly, despite idealized model geometry and forcings. Abrupt changes in flood characteristics, or 'bifurcations', separate regions of parameter space associated with these behaviours. In Section 4 we discuss the implications of our findings for real ice-marginal lakes, moulins and subglacial lakes. 

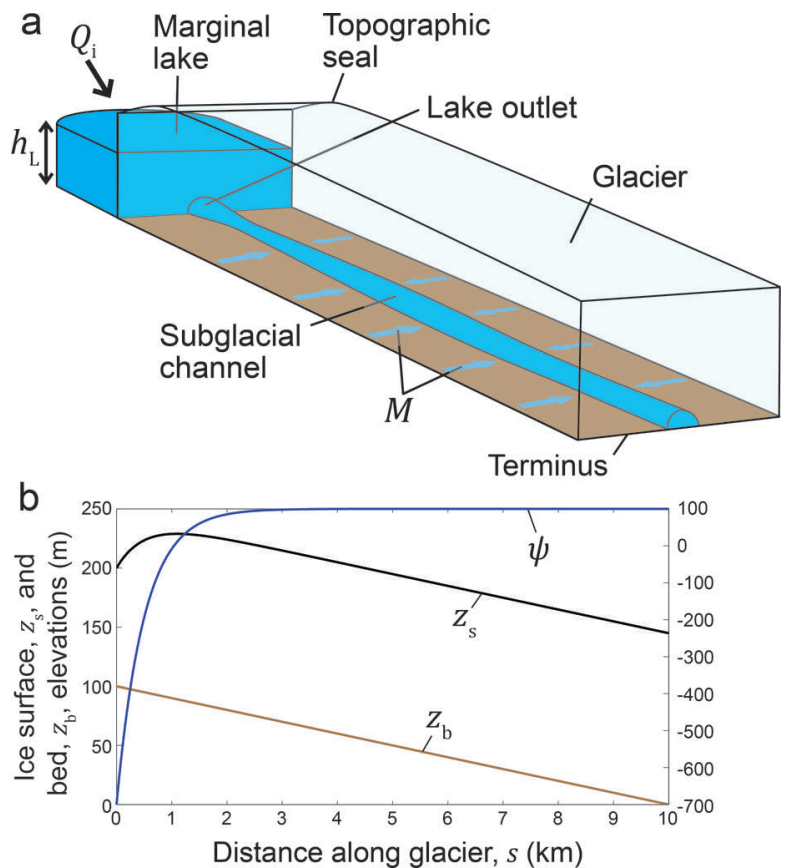

Fig. 1. Our model ice-dammed reservoir system. (a) A subglacial channel is hydraulically coupled to an ice-dammed lake that receives meltwater at a rate $Q_{\mathrm{i}}$. The channel receives a constant and uniform supply of water along its length $M$. (b) The prescribed basic hydraulic gradient $\psi$ (blue curve) is negative near the lake - a topographic seal. Also displayed is an example pair of ice surface and bed profiles $\left(z_{\mathrm{s}}\right.$ and $z_{\mathrm{b}}$; black and brown curves) that would produce this hydraulic gradient. In this example the bed slope $\varphi_{\mathrm{b}}=0.01$

\section{METHODS}

\subsection{Model}

Our model closely resembles that described by Fowler (1999). It consists of a subglacial channel hydraulically coupled (in terms of both water discharge and pressure) to an ice-dammed lake (Fig. 1). The most important difference between our model and Fowler's is our addition of a seasonally varying lake input. Model variables and parameters are summarized in Tables 1 and 2 .

The ice-dammed lake is vertically sided, with a surface area $A=5 \mathrm{~km}^{2}$, and the ice dam has a constant thickness

Table 1. Summary of model variables

\begin{tabular}{|c|c|c|}
\hline Variable & Unit & Definition \\
\hline$h_{\mathrm{L}}$ & $\mathrm{m}$ & Lake depth \\
\hline 1 & $\mathrm{~m}$ & Channel wetted perimeter \\
\hline$m$ & $\mathrm{~kg} \mathrm{~m}^{-1} \mathrm{~s}^{-1}$ & Channel melt rate per unit distance \\
\hline M & $\mathrm{m}^{2} \mathrm{~s}^{-1}$ & Supply of water to the channel \\
\hline$N$ & $\mathrm{~Pa}$ & Channel effective pressure \\
\hline$P_{\mathrm{i}}$ & $\mathrm{Pa}$ & Ice overburden pressure \\
\hline$Q$ & $\mathrm{~m}^{3} \mathrm{~s}^{-1}$ & Channel discharge \\
\hline$Q_{\mathrm{i}}$ & $\mathrm{m}^{3} \mathrm{~s}^{-1}$ & Input to the lake \\
\hline$s$ & $\mathrm{~m}$ & Distance along channel \\
\hline$S$ & $\mathrm{~m}^{2}$ & Channel cross-sectional area \\
\hline$t$ & $\mathrm{~s}$ & Time \\
\hline$T$ & ${ }^{\circ} \mathrm{C}$ & Air temperature \\
\hline$\psi$ & $\mathrm{Pa} \mathrm{m}^{-1}$ & Basic hydraulic gradient \\
\hline
\end{tabular}

Table 2. Model parameters and physical constants

\begin{tabular}{lcc}
\hline Parameter/ & Description & Value \\
constant & & \\
\hline$A$ & Lake area & \\
$f$ & Hydraulic roughness of channel & $0.07 \mathrm{~m} \mathrm{~m}^{2 / 3} \mathrm{~s}^{2}$ \\
$g$ & Acceleration due to gravity & $9.8 \mathrm{~m} \mathrm{~s}^{-2}$ \\
$H$ & Ice dam thickness & $100 \mathrm{~m}^{-1}$ \\
$k$ & Melt model constant & $2 \mathrm{~m}^{3} \mathrm{~s}^{-1} \mathrm{~K}^{-1}$ \\
$K_{0}$ & Ice-rheology law constant & $10^{-24} \mathrm{~Pa}^{-3} \mathrm{~s}^{-1}$ \\
$L$ & Latent heat of fusion of water & $334 \mathrm{~kJ} \mathrm{~kg}^{-1}$ \\
$n$ & Ice-rheology law exponent & $3 \mathrm{~m}^{1 / 3} \mathrm{~s}$ \\
$n^{\prime}$ & Manning's roughness coefficient & $0.1 \mathrm{~m}^{-3}$ \\
$\rho_{\mathrm{w}}$ & Water density & $1000 \mathrm{~kg} \mathrm{~m}^{-3}$ \\
$S_{0}$ & Length of glacier & $10000 \mathrm{~m}^{2}$ \\
$T_{\mathrm{m}}$ & Peak air temperature & $0.1-28^{\circ} \mathrm{C}$ \\
$V_{\mathrm{A}}$ & Total annual input to lake & $3.15 \times 10^{7} \mathrm{kT}_{\mathrm{m}} / \pi \mathrm{m}^{3}$ \\
$V_{\mathrm{F}}$ & Total volume of lake when full & $0.45 \mathrm{~km}^{3}$ \\
$\rho_{\mathrm{i}}$ & Ice density & $900 \mathrm{~kg} \mathrm{~m}^{-3}$ \\
$\varphi_{\mathrm{b}}$ & Channel slope & 0.01 \\
$\psi_{0}$ & Basic hydraulic gradient scale & $100 \mathrm{~Pa} \mathrm{~m}^{-1}$ \\
& & \\
\hline
\end{tabular}

$H=100 \mathrm{~m}$. Its depth $h_{\mathrm{L}}$ evolves with time $t$ due to input $Q_{\mathrm{i}}$ and water exchange with the subglacial channel (Fig. 1) according to

$$
\frac{\mathrm{d} h_{\mathrm{L}}}{\mathrm{d} t}=\frac{1}{A}\left[Q_{\mathrm{i}}-Q(s=0, t)\right],
$$

where $Q$ is the discharge in the channel and the spatial coordinate $s$ is zero at the lake and $s_{0}(=10 \mathrm{~km})$ at the glacier terminus. The lake's depth provides the boundary condition on the channel's effective pressure $N$ (equal to the difference between the ice-overburden and water pressures) at the lake outlet: $N(0, t)=\rho_{\mathrm{i}} g H-\rho_{\mathrm{w}} g h_{\mathrm{L}}$, where $\rho_{\mathrm{i}}$ is the ice density $\left(900 \mathrm{~kg} \mathrm{~m}^{-3}\right), \rho_{\mathrm{w}}$ is the water density $\left(1000 \mathrm{~kg} \mathrm{~m}^{-3}\right)$ and $g$ is the acceleration due to gravity $\left(9.8 \mathrm{~m} \mathrm{~s}^{-2}\right)$. One choice for the boundary condition on $N$ at $s=s_{0}$ is $N\left(s_{0}, t\right)=0$ (e.g. $N g$, 1998; Kingslake, 2013). However, to simplify the numerics, we assume that drainage is controlled by a boundary layer in the channel's effective pressure near the lake. Hence this boundary condition is replaced by $\partial N / \partial s=0$ (Fowler, 1999). The qualitative behaviour of the model is not affected by this simplification (Evatt, 2006; Kingslake, 2013).

The evolution of the channel's cross-sectional area is controlled by the competition between melt enlargement and creep closure:

$$
\frac{\partial S}{\partial t}=\frac{m}{\rho_{\mathrm{i}}}-K_{0} S N^{n},
$$

where $n=3$ and $K_{0}=10^{-24} \mathrm{~Pa}^{-3} \mathrm{~s}^{-1}$ are temperate icerheology parameters (Fowler, 1999) and $m$ is the rate of frictional channel-wall melting per unit distance $((\psi+\partial N / \partial s)|Q| / L$, where $L$ is the latent heat of fusion of water $\left(334 \mathrm{~kJ} \mathrm{~kg}^{-1}\right)$ and $\psi$ is the basic hydraulic gradient). This assumes that the water is at the pressure-melting point and all the energy it gains as it flows through the total hydraulic gradient $(\psi+\partial N / \partial s)$ is used locally for melting (Fowler, 1999). Ignoring a small contribution from the changing channel area, water mass continuity gives

$$
\frac{\partial Q}{\partial s}=M
$$

where $M$ is a constant, uniform input to the channel along its length $\left(7 \times 10^{-4} \mathrm{~m}^{2} \mathrm{~s}^{-1}\right)$. We use Manning's equation to 
a

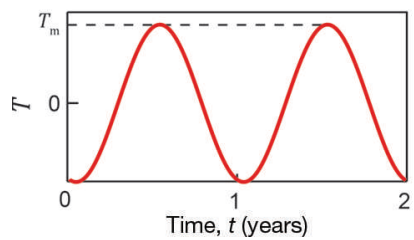

b

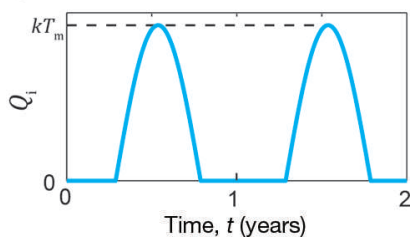

Fig. 2. Synthetic air temperature and lake input time series defined by Eqns (6) and (7).

parameterize momentum balance in the turbulent water flow:

$$
\frac{\partial N}{\partial s}=f \rho_{\mathrm{w}} g \frac{Q|Q|}{S^{\frac{8}{3}}}-\psi,
$$

where $f$ is the hydraulic roughness $\left(n^{\prime 2}\left(I^{2} / S\right)^{2 / 3} \approx 0.07 \mathrm{~m}^{2 / 3} \mathrm{~s}^{2}\right.$ for a semicircular channel with wetted perimeter $I$ and Manning's roughness coefficient $n^{\prime}=0.1 \mathrm{~m}^{1 / 3} \mathrm{~s}$; Fowler, 1999; Kingslake and $\mathrm{Ng}, 2013 \mathrm{a}$ ). Water flow is driven by the total hydraulic gradient $\psi+\partial N / \partial s$. This contains a dynamic component $\partial N / \partial s$ and a component that depends on glacier shape - the basic hydraulic gradient $\psi\left(=\rho_{\mathrm{w}} g \sin \right.$ $\varphi_{\mathrm{b}}-\partial P_{\mathrm{i}} / \partial s$, where $\varphi_{\mathrm{b}}$ is the channel slope and $P_{\mathrm{i}}$ is the ice overburden pressure). To encourage the simulation of stable flood cycles, the prescribed glacier shape is such that $\psi$ is negative near the lake (Fig. 1b):

$$
\psi=\psi_{0}\left[1-8 \exp \left(-20 \frac{s}{s_{0}}\right)\right],
$$

where $\psi_{0}=100 \mathrm{~Pa} \mathrm{~m}^{-1}$

To simulate seasonal weather variations and drive a simple model of lake input $Q_{i}$ we use a synthetic sinusoidal air temperature time series,

$$
T=T_{\mathrm{m}} \sin [2 \pi(t-0.29)],
$$

where $t$ has units of years and integer $t$ corresponds to the beginning of each calendar year. The 0.29 year offset ensures the maximum air temperature $T_{\mathrm{m}}$ occurs in midsummer. We model meltwater input to the lake $Q_{i}$ by

$$
\begin{aligned}
& Q_{\mathrm{i}}=k T ; T>0 \\
& Q_{\mathrm{i}}=0 ; T \leq 0
\end{aligned}
$$

where $k=2 \mathrm{~m}^{3} \mathrm{~s}^{-1} \mathrm{~K}^{-1}$, close to the value of a similar parameter derived empirically by Kingslake and $\mathrm{Ng}$ (2013b). Figure 2 plots our synthetic air temperature time series, as defined by Eqn (6), and the corresponding time series of meltwater input to the lake, as defined by Eqn (7).

\subsection{Parameters}

The model includes several physical parameters that are poorly constrained by observations (Table 2). The Manning's roughness coefficient $n^{\prime}=0.1 \mathrm{~m}^{1 / 3} \mathrm{~s}$ and the ice-rheology parameters $n$ and $K_{0}$ are chosen based on previous similar studies (Fowler, 1999; Evatt and others, 2006; Kingslake and $\mathrm{Ng}, 2013 \mathrm{a})$. The constant supply of water to the channel along its length $M=7 \times 10^{-4} \mathrm{~m}^{2} \mathrm{~s}^{-1}$ implies a reasonable background terminus discharge of $s_{0} M=7 \mathrm{~m}^{3} \mathrm{~s}^{-1}$. We expect the results of our analysis not to depend qualitatively on these parameter values.

To parameterize the basic hydraulic gradient, Fowler (1999) proposed Eqn (5) based on observations of ice thickness from Vatnajökull, Iceland (Björnsson, 1992). An area of negative hydraulic gradient near the lake, or

'topographic seal', encourages stable flood cycles in the model via the formation of a subglacial hydraulic divide. Kingslake (2013) and Kingslake and Ng (2013a) showed that a topographic seal is not a requirement for divide formation or for the simulation of stable flood cycles. We impose a topographic seal in this study to increase the range of parameter space over which stable flood cycles can be simulated. Qualitatively the model's behaviour is independent of the details of the seal (Kingslake, 2013).

The formation of the hydraulic divide does require a nonzero channel input $M$, because when $M=0, Q$ is uniform (Eqn (3)). Without the stabilizing effect of divide formation, simulated floods grow unstably $(\mathrm{Ng}, 1998$; Fowler, 1999; Kingslake, 2013; Kingslake and Ng, 2013a). This is unrealistic, therefore we use a positive channel input $M$ to allow us to simulate stably repeating floods.

\subsection{Numerics}

To explore the behaviour of the model we solve its governing equations numerically. Space and time domains are discretized with a grid spacing of $100 \mathrm{~m}$ and time steps of 2.7 hours. Integrating Eqn (3) and combining the result with the terminus boundary condition on $N$ and Eqn (4) yields

$$
Q(s, t)=\sqrt{S\left(s_{0}, t\right)^{\frac{8}{3}} \psi\left(s_{0}\right) / f \rho_{\mathrm{w}} g}-M\left[s_{0}-s\right] .
$$

With $Q$ calculated using this expression, $N$ is found by integrating Eqn (4) from the lake, where $N$ is determined by the lake depth $\left(N(0, t)=\rho_{\mathrm{i}} g H-\rho_{\mathrm{w}} g h_{\mathrm{L}}\right)$, to the terminus. With $Q$ and $N$ known everywhere, $h_{\mathrm{L}}$ and $S$ are evolved forward in time using Eqns (1) and (2) and the forward Euler method, with $Q_{i}$ given by Eqns (6) and (7). Fowler (1999), Evatt (2006) and Kingslake (2013) provide more details.

\subsection{Experimental design}

We conduct a suite of numerical model simulations during which the parameter $T_{\mathrm{m}}$ is varied systematically $\left(0.1 \leq T_{\mathrm{m}}\right.$ $\leq 28^{\circ} \mathrm{C}$ ) between simulations and kept constant during each simulation. During this exploration of $T_{\mathrm{m}}$ parameter space, all other parameters are kept constant. Unless otherwise stated, all the simulations start with $h_{\mathrm{L}}=40 \mathrm{~m}$ and a uniform channel cross-sectional area $\sim 5 \mathrm{~m}^{2}$, and continue for 120 model years.

\section{RESULTS}

To demonstrate several interesting aspects of the model's behaviour, we first discuss the results of three simulations that lie in three crucial regions of $T_{\mathrm{m}}$ parameter space. The model produces qualitatively different flood cycles in each region and we present the results in the form of time series of lake input and discharge, and phase-space portraits that plot lake discharge against lake level. Next we plot the peak discharge of all the floods in all our simulations against the parameter $T_{\mathrm{m}}$ used to simulate them. This reveals regions of parameter space associated with mode locking, resonance and chaos, and the abrupt transitions, or bifurcations, that separate them. Finally we investigate the properties of chaotic model solutions and two types of bifurcation.

\subsection{Flood cycles}

Figure 3 plots flood cycles simulated using three different values of the midsummer air temperature $T_{\mathrm{m}}$. Figure $3 \mathrm{a}, \mathrm{c}$ and e display 20 year time series of discharge at the lake 

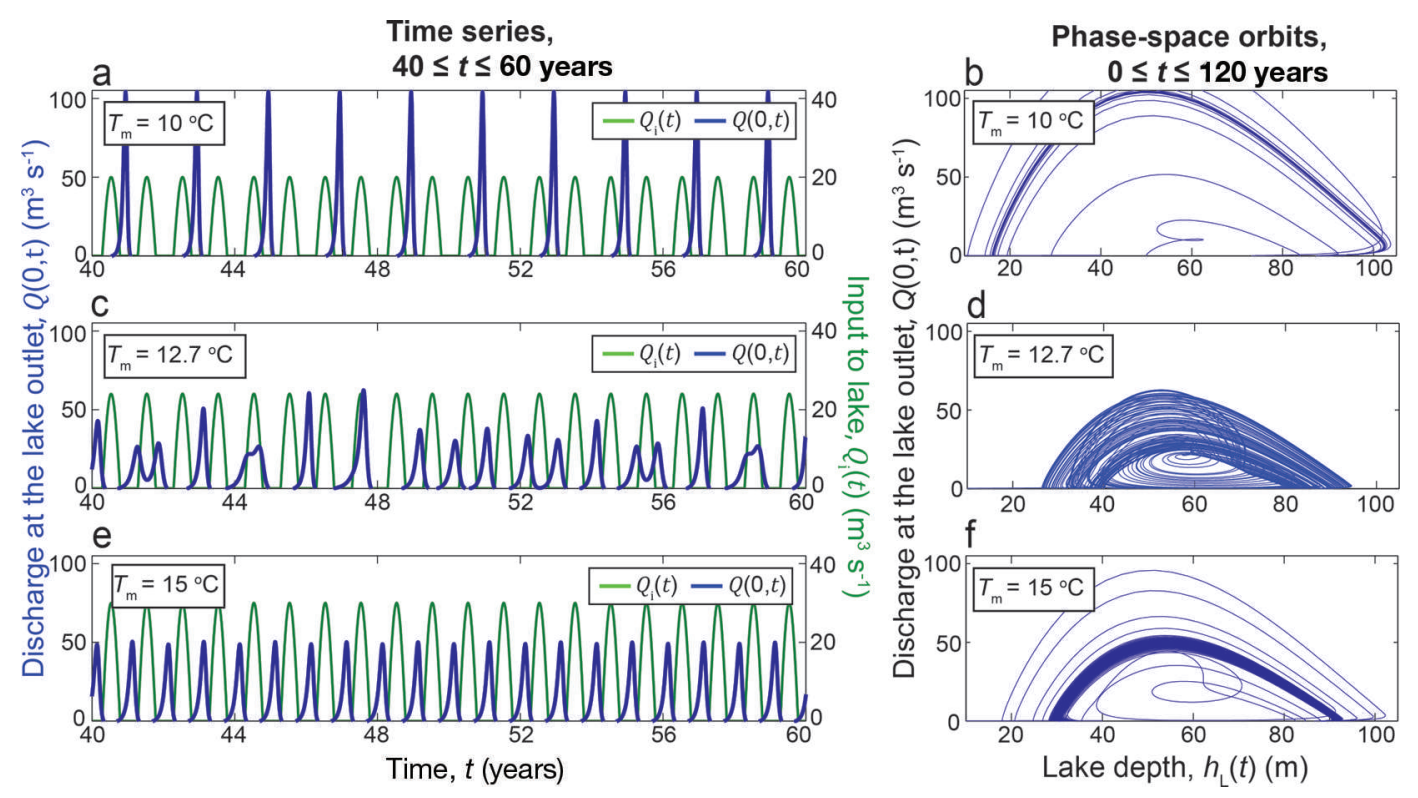

Fig. 3. Simulated flood cycles. Results from three simulations using seasonally varying air temperatures to drive lake input, with (a, b) $T_{\mathrm{m}}=10^{\circ} \mathrm{C}$, (c, d) $T_{\mathrm{m}}=12.7^{\circ} \mathrm{C}$ and $(\mathrm{e}, \mathrm{f}) T_{\mathrm{m}}=15^{\circ} \mathrm{C}$. (a, c, e) Time series of discharge at the lake outlet $Q(0, t)$ (blue curves) and lake input $Q_{\mathrm{i}}(t)$ (green curves) for 20 model years after transients have ended. (b, d, f) Solution orbits in $Q(0, t)-h_{\mathrm{L}}(t)$ phase space from the complete 120-year-long simulations.

outlet, $Q(0, t)$, extracted from the results of three simulations that use $T_{\mathrm{m}}=10^{\circ} \mathrm{C}, T_{\mathrm{m}}=12.7^{\circ} \mathrm{C}$ and $T_{\mathrm{m}}=15^{\circ} \mathrm{C}$. Figure $3 \mathrm{~b}, \mathrm{~d}$ and $f$ show corresponding orbits in $Q(0, t)-h_{\mathrm{L}}(t)$ phase space.

When $T_{\mathrm{m}}=10^{\circ} \mathrm{C}$ and $15^{\circ} \mathrm{C}$, after transients, the system approaches limit cycles with repeat times of 2 years and 1 year respectively (Fig. $3 \mathrm{a}$ and e). The sequence of lake filling, channel enlargement through melt, lake highstand and drainage has been described elsewhere (Nye, 1976; Fowler, 1999, 2009; Ng and Björnsson, 2003; Kingslake and $\mathrm{Ng}, 2013 \mathrm{a})$. Note that the discharge at the lake outlet is negative between floods; a hydraulic divide forms in the channel near the lake. Fowler (1999) showed how the dynamics of this divide cause flood size to increase with $Q_{i}$ when this input is kept constant (Kingslake, 2013: ch. 3). Contrary to expectations based on these previous analyses, the warmer simulation $\left(T_{\mathrm{m}}=15^{\circ} \mathrm{C}\right.$; Fig. $3 \mathrm{e}$ and $\left.\mathrm{f}\right)$, with the higher mean lake input, produces flood cycles with a lower peak discharge (cf. Fig. 3a and e).

When $T_{\mathrm{m}}=12.7^{\circ} \mathrm{C}$, flood cycles are simulated but they do not approach limit cycles (Fig. 3c and d). Instead the cycles appear random, never reaching a repeating orbit in $Q(0, t)-h_{\mathrm{L}}(t)$ phase space (Fig. $\left.3 \mathrm{~d}\right)$. We will show that these cycles exhibit chaotic characteristics.

\subsection{Mode locking}

Figure 4 plots the results of many simulations during which we record the peak discharge of each flood. Each point in Figure 4 plots one flood's peak discharge (vertical axis) against the value of $T_{\mathrm{m}}$ used in the simulation that produced that flood (horizontal axis). The colour of each point indicates the day of the year on which the flood peak occurred.

In the regions of $T_{\mathrm{m}}$ parameter space around $T_{\mathrm{m}}=10^{\circ} \mathrm{C}$ and $T_{\mathrm{m}}=15^{\circ} \mathrm{C}$, floods occur progressively later in the year as $T_{\mathrm{m}}$ decreases (green arrows; Fig. 4a). Moreover, instead of floods occurring less often as $T_{\mathrm{m}}$ decreases, the mean time between floods (hereafter referred to as the repeat time) remains constant and peak discharges decrease to compensate for the decrease in time-averaged lake input (Fig. 4a).
This behaviour is analogous to 'mode locking' of periodically forced nonlinear oscillators, when the frequency of an oscillator's response stays locked to that of the frequency of the forcing. This can occur when the frequency of the forcing is comparable to an oscillator's natural frequency. Similarly, the mode-locking behaviour of our model only manifests when the timescales of the lakedepth and subglacial-channel evolution, predominantly controlled by the lake surface area and glacier geometry respectively (Section 2), are comparable to the periodicity of the time-varying meltwater input (1 year).

\subsection{Resonance}

As $T_{\mathrm{m}}$ decreases from $15^{\circ} \mathrm{C}$ to $10^{\circ} \mathrm{C}$, the peak discharges of floods increase and their timing in the year shifts abruptly (Fig. 4). When the lake's total annual input $V_{\mathrm{A}}$ is slightly too large to allow it to persist for 2 years before draining (e.g. when $T_{\mathrm{m}}=15^{\circ} \mathrm{C}$ ), relatively small floods occur every year. When $T_{\mathrm{m}}$ is smaller (e.g. when $T_{\mathrm{m}}=10^{\circ} \mathrm{C}$ ) the lake can persist for 2 years before draining. Although the timeaveraged lake input is now lower, the flood repeat time is twice as large (2 years instead of 1 year). Hence the total input to the lake between each flood is increased. This increases flood peak discharges.

Floods are largest when the climatic forcing allows the lake to fill completely in an integer number of years. A lake's 'resonant climatic forcing' is any value of $T_{\mathrm{m}}$ that allows the lake basin to fill completely over $n$ years, where $n=1,2,3$, etc. Therefore, there exist multiple resonant values of $T_{\mathrm{m}}$ corresponding to $V_{\mathrm{A}}=V_{\mathrm{F}} / n$, where $V_{\mathrm{F}}$ is the lake's volume when full. This is reflected in Figure 4 by a second resonance peak at $T_{\mathrm{m}} \approx 5.5^{\circ} \mathrm{C}$ and a third at $T_{\mathrm{m}} \approx 2^{\circ} \mathrm{C}$ (not clearly visible at the resolution of Fig. 4). Integrating Eqns (6) and (7) yields $V_{\mathrm{A}}=3.15 \times 10^{7} \mathrm{k} T_{\mathrm{m}} / \pi$. Assuming the lake fills to the flotation level $(9 / 10 H)$ before emptying completely during each flood $\left(V_{\mathrm{F}}=9 / 10 H A\right)$, the $n$th resonant climatic forcing is given by $T_{\mathrm{m}}{ }^{n}=0.9 \pi H A /\left(3.15 \times 10^{7} \mathrm{kn}\right)=\{22.4,11.2,7.5,5.6, \ldots\}^{\circ} \mathrm{C}$. The second resonant $T_{\mathrm{m}}$ value $\left(11.2^{\circ} \mathrm{C}\right)$ matches the 

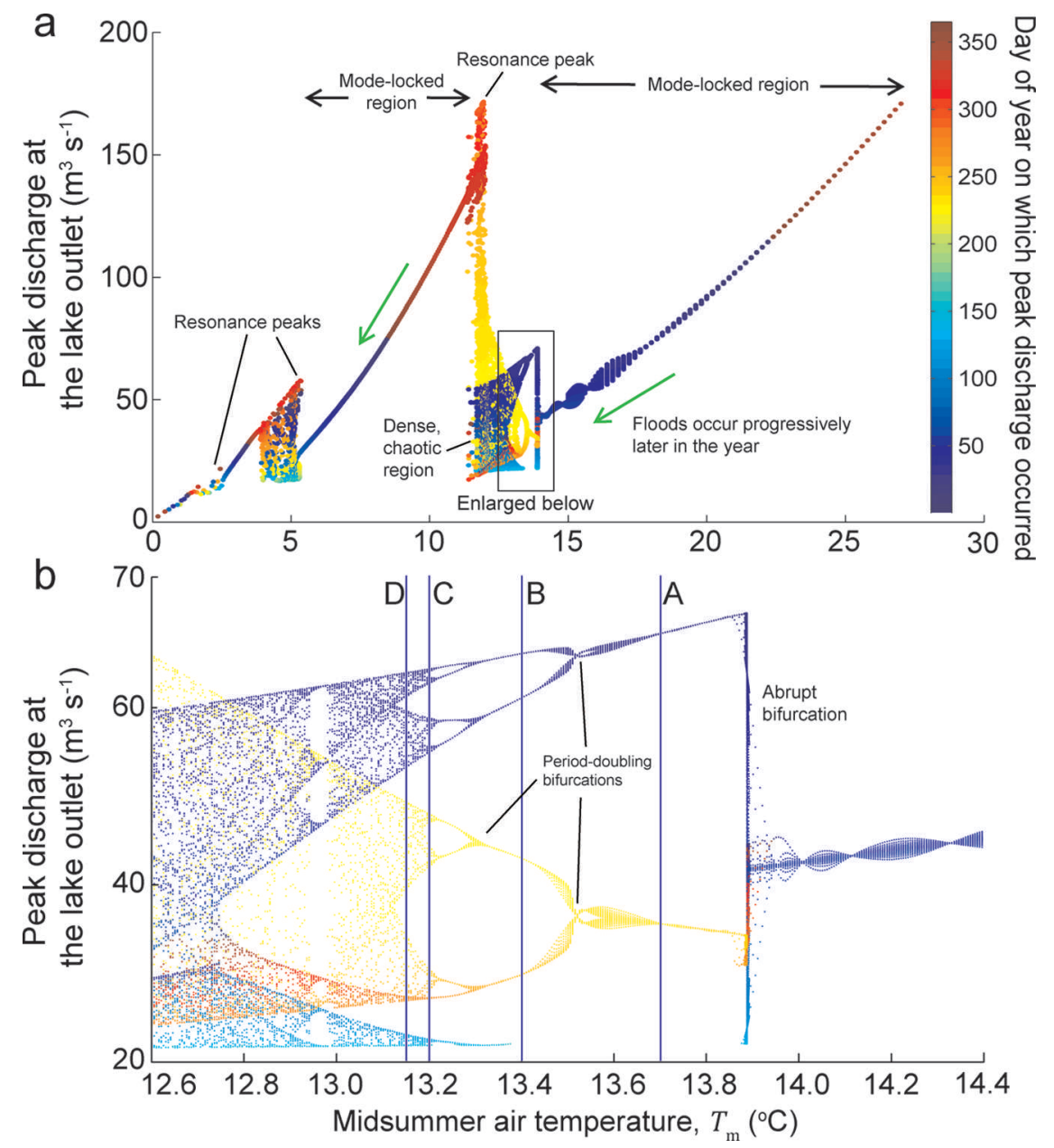

Fig. 4. $T_{\mathrm{m}}$ parameter space. (a) Peak discharge of floods recorded during 120 year simulations plotted against the value of the midsummer air temperature $T_{\mathrm{m}}$ used in each simulation. The first ten flood peaks of each simulation are omitted to remove transients. The black box indicates the region shown in more detail in (b). Horizontal quantization visible in $(\mathrm{a})\left(T_{\mathrm{m}}>16^{\circ} \mathrm{C}\right)$ is the result of a coarse search through this region. The vertical lines in (b) correspond to orbits plotted in Figure 9. Lines that are one point in vertical extent (e.g. $6 \leq T_{\mathrm{m}} \leq 11^{\circ} \mathrm{C}$ and $T_{\mathrm{m}}>19^{\circ} \mathrm{C}$ ) correspond to limit cycles, where all the recorded floods have the same peak discharge; slightly thicker lines (e.g. $14 \leq T_{\mathrm{m}} \leq 17^{\circ} \mathrm{C}$ ) correspond to simulations during which transients lasted longer than ten flood cycles; and large blocks of points indicate dense, chaotic orbits. The colour of each point indicates the day of the year on which the flood peak occurs. In (a) the green arrows indicate two regions where floods occur progressively later in the year as $T_{\mathrm{m}}$ decreases.

numerically simulated resonance peak (Fig. 4). However, when $T_{\mathrm{m}}<10^{\circ} \mathrm{C}$, a significant volume of water is left in the lake after floods and this simple analysis fails.

\subsection{Chaotic dynamics}

Mode-locked regions of parameter space are separated by densely populated regions (Fig. 4) corresponding to dense periodic orbits that never repeat. These orbits are sensitive to their initial conditions. Figure 5 a plots time series of lake depth from two simulations that used $T_{\mathrm{m}}=12.7^{\circ} \mathrm{C}$, with two slightly different initial lake depths, $40.00 \mathrm{~m}$ and $40.01 \mathrm{~m}$. Figure $5 \mathrm{~b}$ and $\mathrm{c}$ plot the trajectories of the two solutions in three-dimensional (3-D) discharge-lake-depth-channel-size $\left(Q(0, t)-h_{\mathrm{L}}(0)-S(0, t)\right)$ phase space, while Figure $5 d$ shows the normalized separation of these orbits. The solutions track each other for $\sim 15$ years before diverging. However, their separation does not grow unboundedly; they remain in the same region of phase space (Fig. $5 b$ and $c$ ), but despite approaching each other at $t \approx 65$ years (Fig. $5 \mathrm{~d}$ ) they never collapse onto a common orbit. This behaviour is indicative of chaotic dynamics and has been studied thoroughly in other fields (e.g. Drazin, 1992; Ott, 2002).
Another indicator of chaotic dynamics is topological mixing of phase space, where orbits fold and bifurcate, visiting every part of a specific region of phase space. Figure 6 plots the trajectory of one simulation (with $T_{\mathrm{m}}=12.7^{\circ} \mathrm{C}$ ) in another 3-D phase space: discharge-lakedepth-time $\left(Q(0, t)-h_{\mathrm{L}}(t)-t\right)$ space. Figure $6 \mathrm{~b}$ displays twodimensional Poincaré sections taken along $Q(0, t)-h_{\mathrm{L}}(t)$ planes, perpendicular to the $t$-dimension, at nine instants in the annual cycle. The trajectory possesses a clear structure; together the points form a shape called an attractor. The 'Nye attractor' rotates, bifurcates and folds over on itself as the sections progress through the annual cycle. This depiction of topological mixing is reminiscent of equivalent plots from studies of nonlinear oscillators (e.g. the Duffing oscillator; Novak and Frehlich, 1982).

\subsection{Bifurcations}

The transition from limit cycles to chaotic cycles around $13<T_{\mathrm{m}}<14^{\circ} \mathrm{C}$ involves two types of bifurcation (Fig. 4). The first, at $T_{\mathrm{m}} \approx 13.88^{\circ} \mathrm{C}$, is an abrupt transition from period- 1 orbits (i.e. limit cycles that complete one orbit before repeating) to period-2 orbits (i.e. limit cycles that complete 
a
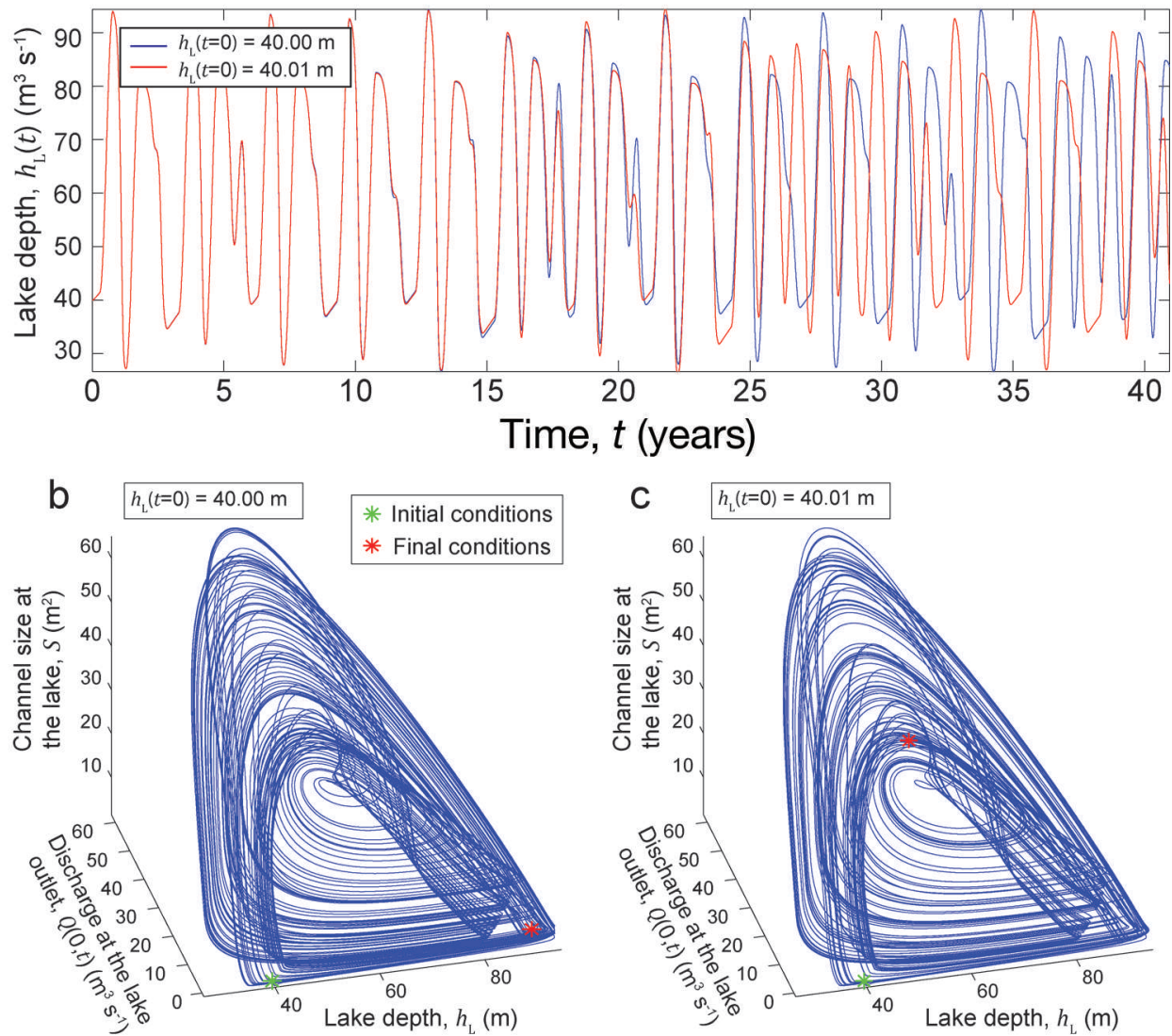

d

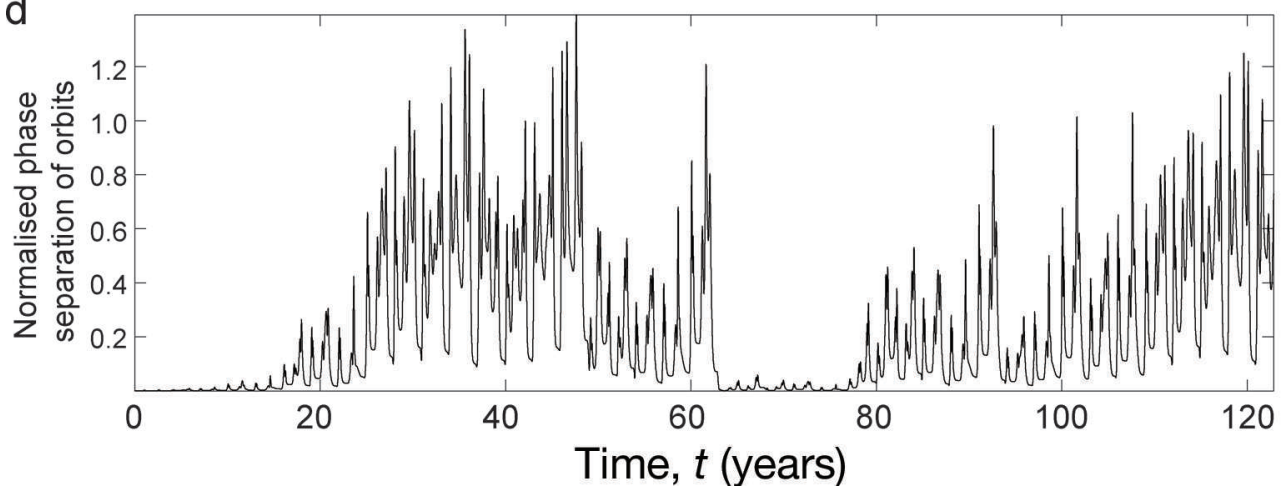

Fig. 5. Sensitivity to initial conditions. (a) Time series of lake depth from two simulations which used $T_{\mathrm{m}}=12.7^{\circ} \mathrm{C}$. Simulations are identical except for a slight difference in their initial lake depth $h_{\mathrm{L}}(0)$. The blue curve corresponds to $h_{\mathrm{L}}(0)=40.00 \mathrm{~m}$, and the red curve corresponds to $h_{\mathrm{L}}(0)=40.01 \mathrm{~m}$. (b, c) Corresponding orbits in $Q(0, t)-h_{\mathrm{L}}(0)-S(0, t)$ phase space, with the initial and final conditions shown in green and red respectively. (d) Time series of the normalized separation between the orbits in (b, c). Normalized separation is calculated by differencing each component of the orbits' positions normalized with the maximum value of the corresponding variable. The Pythagorean sum of the normalized separation is plotted. Note the different time axes in (a) and (d).

two orbits before repeating). Figure 7 displays the orbits in $Q(0, t)-h_{\mathrm{L}}(t)$ phase space of two simulations which lie on each side of this transition in parameter space. Figure 8 plots corresponding time series of $Q_{i}$ and $Q(0, t)$.

Both simulations start on almost identical unstable period-2 orbits (blue points in Fig. 7), in which every second flood is double-peaked (Fig. 8a; note that the two orbits appear as one curve in Fig. 8a). The onset of melt in spring occurs just after the first peak and instigates the second (Fig. 8a). Larger floods occur every third winter. The simulations leave these orbits in two different ways.

During the warmer simulation $\left(T_{\mathrm{m}}=13.888002^{\circ} \mathrm{C}\right)$, floods occur progressively earlier each year and the double-peaked flood evolves into two floods of equal size
(Fig. 8c). Meanwhile, the originally larger flood shrinks. The result is limit cycles with a repeat time of 1 year consisting of equally sized floods (red points, Fig. 7b; Fig. 8c). During the cooler simulation $\left(T_{\mathrm{m}}=13.888000^{\circ} \mathrm{C}\right)$, floods occur progressively later until the first peak of the double-peaked flood shrinks and disappears, resulting in limit cycles where every other flood is roughly twice as large as the others and the mean flood repeat time is 1.5 years (red points, Fig. 7a; Fig. 8b).

After this abrupt bifurcation, further decrease in $T_{\mathrm{m}}$ leads to a cascade of period-doubling bifurcations. Figure 9 plots four solution orbits in $Q(0, t)-h_{\mathrm{L}}(t)$ phase space corresponding to $T_{\mathrm{m}}$ values that bracket several period-doubling bifurcations (vertical solid lines in Fig. 4b). As $T_{\mathrm{m}}$ is 

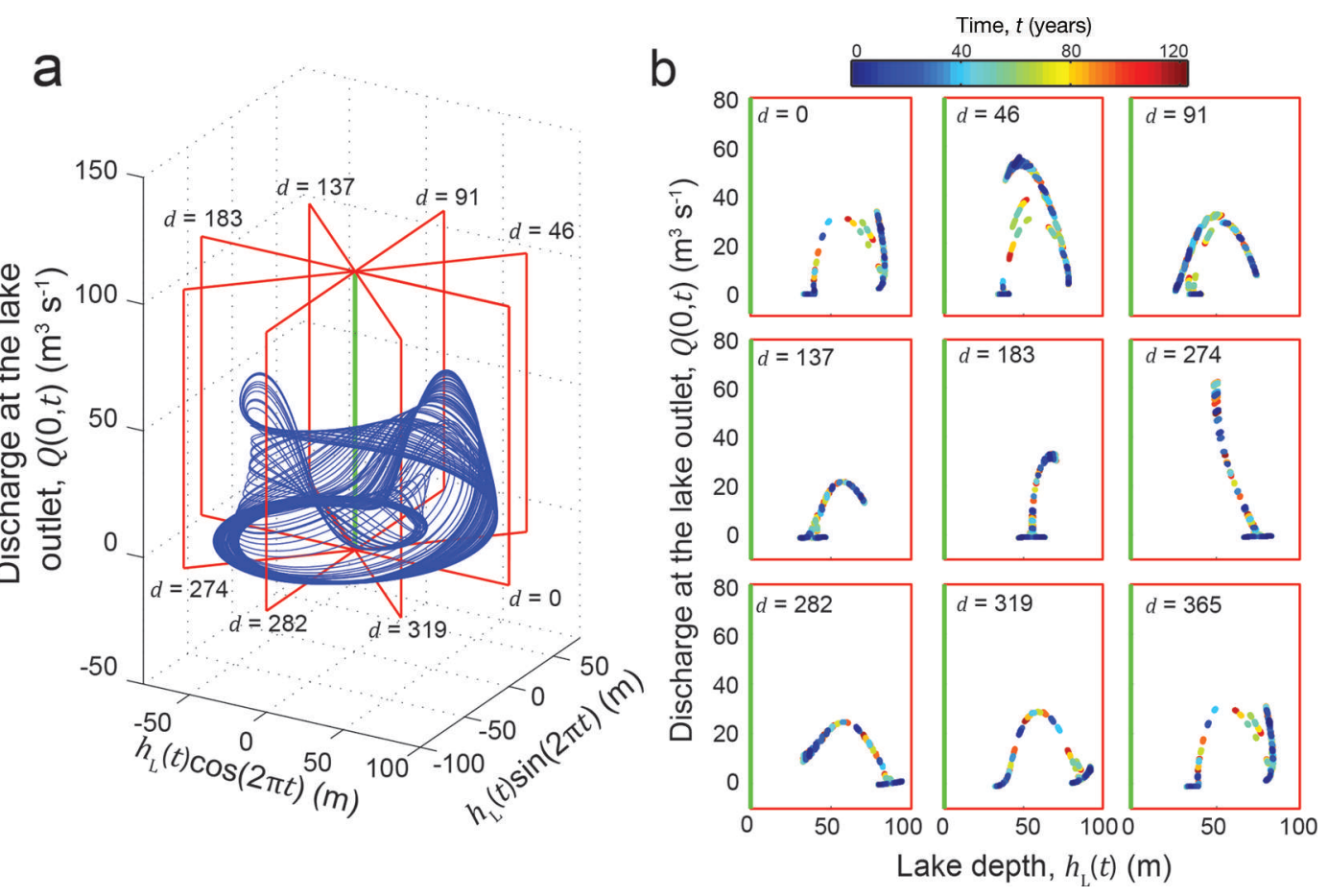

Fig. 6. The Nye attractor and topological mixing of phase space. (a) A solution orbit in $Q(0, t)-h_{\mathrm{L}}(t)-t$ phase space of a simulation that used $T_{\mathrm{m}}=12.7^{\circ} \mathrm{C}$ and $h_{\mathrm{L}}(t=0)=40 \mathrm{~m}$. The blue curve's distance from the vertical green line denotes the lake depth $h_{\mathrm{L}}(t)$, its position along the vertical axis denotes the discharge at the lake $Q(0, t)$ and its rotation around the green line denotes the fractional part of time $t$ multiplied by $2 \pi$ (one rotation corresponds to 1 year). (b) Poincaré sections taken perpendicular to the $t$-dimension at nine different stages of the year, denoted by the day of the year $d$. The points locate the intersection of the orbit with each section. Each section's location in $Q(0, t)-h_{\mathrm{L}}(t)-t$ space is indicated by the boxes in (a). The colour of the points indicates simulation time $t$.

decreased past each bifurcation, the orbit split into two branches and the period of the orbit doubles. Many such bifurcations lead to the densely populated chaotic region on the left of Figure $4 \mathrm{~b}$.

\section{DISCUSSION}

When it is forced with constant meltwater inputs, Nye's (1976) jökulhlaup model simulates floods whose magnitudes increase with the input to the lake; the faster a lake is supplied with water, the larger the floods it produces (Clarke, 1982; Fowler, 1999; Ng and others, 2007; Kingslake, 2013). We have demonstrated a more complex relationship between meltwater input and flood size by prescribing a more realistic, time-varying lake input. Interactions between the timing of lake drainage and a seasonal

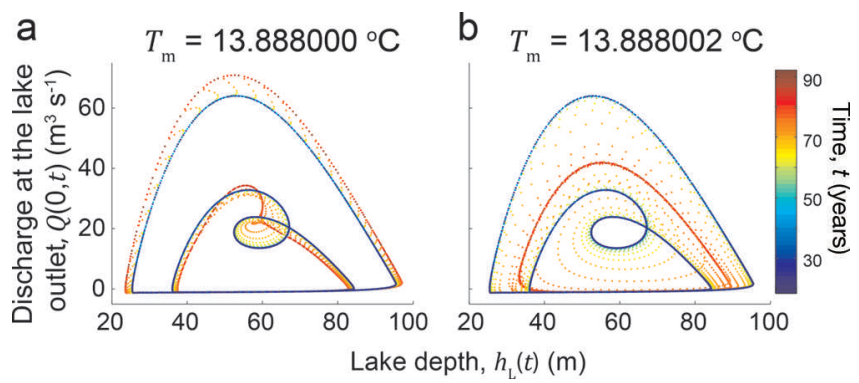

Fig. 7. Orbits in $Q(0, t)-h_{\mathrm{L}}(t)$ phase space of solutions with (a) $T_{\mathrm{m}}=13.888000^{\circ} \mathrm{C}$ and (b) $T_{\mathrm{m}}=13.888002^{\circ} \mathrm{C}$, which lie on each side of an abrupt bifurcation in $T_{\mathrm{m}}$ parameter space (Fig. 4) for $20 \leq t \leq 90$ years. Points are colored to indicate simulation time $t$ and are separated by $\sim 4.5$ model days. cycle of lake input produce mode locking, resonance and chaotic dynamics, behaviours also exhibited by theoretical and observed nonlinear oscillators forced periodically (Moon and Holmes, 1979; Novak and Frehlich, 1982; Drazin, 1992; Kanamaru, 2007). Their discovery in a glaciohydraulic model is interesting mathematically and may have implications for our understanding and the predictability of real-world ice-dammed reservoirs.

In comparison to real systems our model is simple. It neglects the glacier-wide subglacial drainage system and its winter shutdown, lake sensible heat, the pressure dependence of the melting point of ice, glaciological processes influencing ice-dam geometry and the coupling of glacier flow with drainage. Some models have considered some of these complications (e.g. Clarke, 2003; Flowers and others, 2004; Fowler, 2009; Hewitt, 2011; Pimentel and Flowers, 2011; Kingslake, 2013; Kingslake and Ng, 2013a; Werder and Joughin, 2013; Werder and others, 2013) and future work could incorporate them into a more realistic jökulhlaup model. At present, our results cannot be assessed quantitatively against real jökulhlaup systems, not least because our meltwater input model (Eqn (7)) and our prescription of a constant supply of water to the channel along its length are too simplistic. However, our simple approach considering only the essential physics has revealed underlying dynamics of jökulhlaup-like systems that would be difficult to tease out from the behaviour of a more complex model.

Changes in the meltwater input to real ice-dammed lakes affect the size and timing of floods. While a jökulhlaup system remains mode-locked these changes should occur gradually and predictably (e.g. $T_{\mathrm{m}}>13^{\circ} \mathrm{C}$; Fig. 4). Gradual timing shifts have been observed at Merzbacher Lake, Kyrgyzstan (Ng and Liu, 2009), and Gornersee, Switzerland 
a

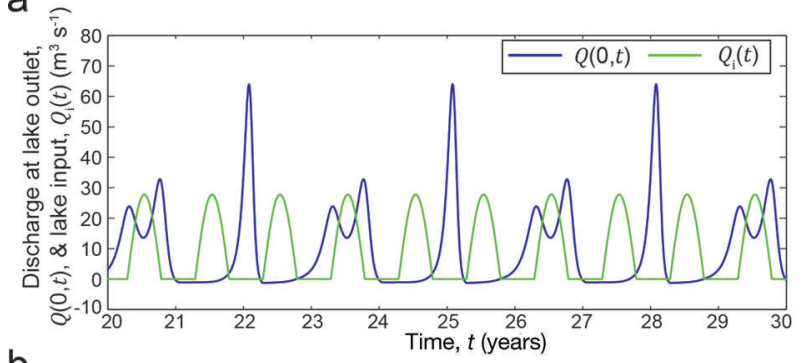

b

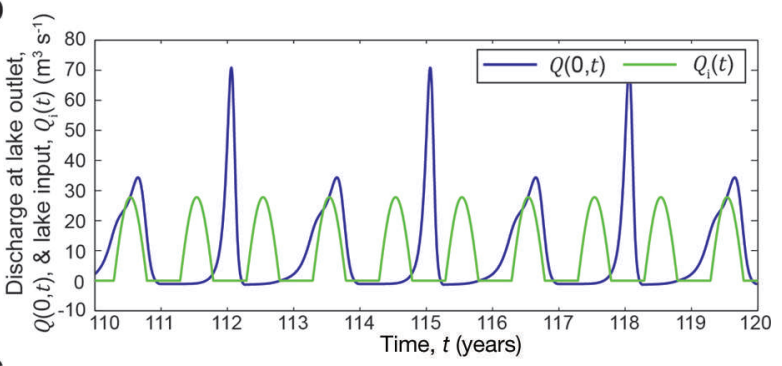

C

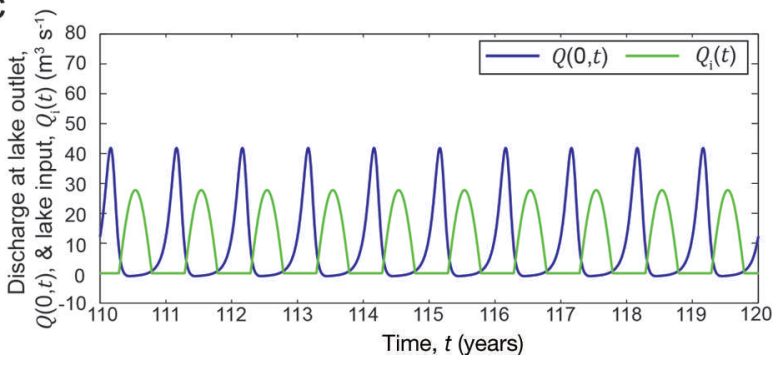

Fig. 8. Time series of lake input $Q_{i}$ and discharge through the lake outlet $Q(0, t)$ from two simulations that lie close to the abrupt bifurcation at $T_{\mathrm{m}} \approx 13.88^{\circ} \mathrm{C}$. (a) Initial $Q_{\mathrm{i}}(t)$ and $Q(0, t)$ time series from two simulations that used $T_{\mathrm{m}}=13.888000^{\circ} \mathrm{C}$ and $T_{\mathrm{m}}=13.888002^{\circ} \mathrm{C}$. (b, c) Long-time time series of the same variables from simulations that used $T_{\mathrm{m}}=13.888000^{\circ} \mathrm{C}$ and $T_{\mathrm{m}}=13.888002^{\circ} \mathrm{C}$ respectively.

(Huss and others, 2007), with annual floods occurring progressively earlier in the year. These shifts in flood timing are consistent with long-term increases in meltwater production and our results suggest that jökulhlaup systems are also capable of undergoing more abrupt changes in both the timing and the peak discharge of floods.

These abrupt changes and the other complicated dynamics our model exhibits are produced purely by the system's internal mechanisms; the model's geometry and forcings are idealized and are kept constant during simulations and yet, in some areas of parameter space, simulated time series appear random, never repeat and are sensitive to initial conditions. Combined with chaotic variations in weather forcing, these dynamics may compound the difficulties of flood prediction associated with uncertain flood-triggering mechanisms and meteorological inputs (Ng and Liu, 2009; Kingslake and Ng, 2013b) and make long-term prediction of flood timing difficult. Due to their sensitive dependence on initial conditions, chaotic systems are practically unpredictable beyond a certain time in the future (e.g. Ott, 2002). However, Kingslake and $\mathrm{Ng}(2013 \mathrm{~b})$ showed that useful prediction of an upcoming flood is possible. Consideration of the dynamics revealed in the present work could help with efforts to predict the long-term evolution of mountain jökulhlaup systems (e.g. Ng and others, 2007; Shen and others, 2007).

To exhibit mode locking, resonance and chaos, a subglacially draining ice-dammed reservoir requires its
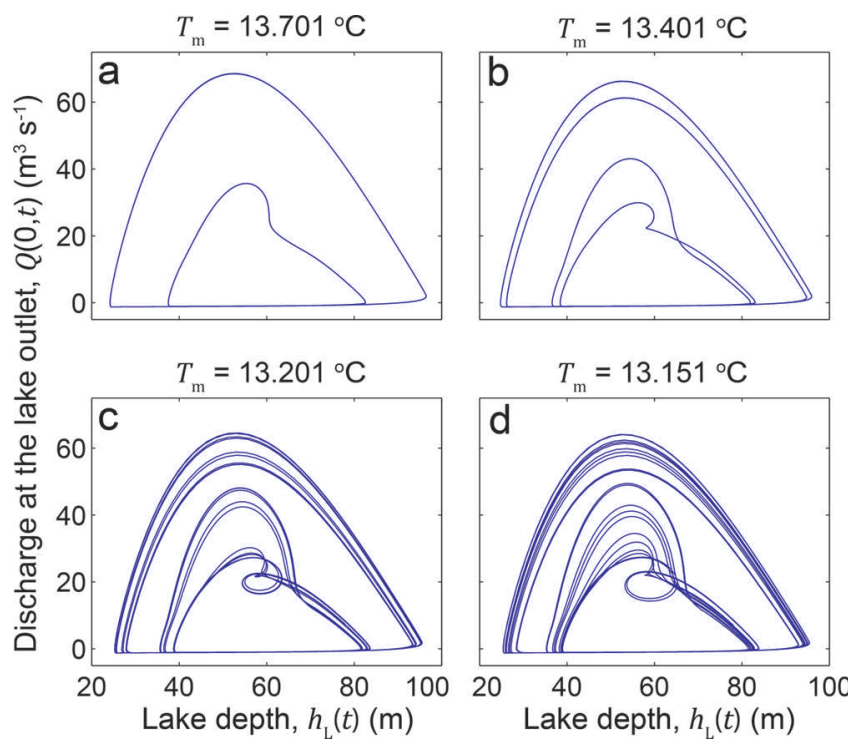

Fig. 9. Period-doubling bifurcations. Long-time solution orbits (transients have been removed) in $Q(0, t)-h_{\mathrm{L}}(t)$ phase space of four simulations that used (a) $T_{\mathrm{m}}=13.701^{\circ} \mathrm{C}$, (b) $T_{\mathrm{m}}=13.401{ }^{\circ} \mathrm{C}$, (c) $T_{\mathrm{m}}=13.201^{\circ} \mathrm{C}$ and (d) $T_{\mathrm{m}}=13.151^{\circ} \mathrm{C}$. (a-d) correspond respectively to the positions in $T_{\mathrm{m}}$-parameter space indicated in Figure $4 \mathrm{~b}$ by the vertical lines A-D.

input, water depth and subglacial drainage system to evolve on comparable timescales. Suppose, for example, our model jökulhlaup system was forced with a diurnally varying meltwater input. These interesting dynamics would not operate. Lake filling would be intermittent and flood discharge would contain a diurnally varying component, but qualitatively the system would behave identically to a system forced with a constant lake input equal to the timeaveraged value of the diurnally varying input. Equally, a jökulhlaup lake several orders of magnitude smaller in area than the one we simulate would fill and drain too quickly for a seasonally varying forcing to induce mode locking, resonance or chaotic dynamics.

Taking into account this requirement on the evolution timescales of reservoir input, depth and drainage, should we expect to find similar dynamics in other ice-dammed reservoir systems? Moulin drainage timescales could fulfil this requirement. Moulins receive diurnally varying inputs and are typically much narrower than jökulhlaup lakes, so the water depth and meltwater input could vary on similar timescales. Furthermore, the e-folding timescale of the size of a channel that closes under the overburden pressure of an ice sheet of thickness $H=500 \mathrm{~m}$ is $\left(K_{0} \rho_{i} g H\right)^{-3} \approx 0.1$ day (Eqn (2)). Beneath Antarctica, meltwater production, uncoupled from surface conditions, may evolve more slowly than subglacial lakes fill and drain, which occurs over months to years (e.g. Wingham and others, 2006; Siegfried and others, 2014). However, lakes can be hydraulically connected over large distances (e.g. Fricker and Scambos, 2009). Hence, a downstream lake could be supplied by an upstream periodically draining lake with an input that varies on timescales conducive to chaotic dynamics. A full analysis of these two important ice-dammed reservoir systems using our model is needed to assess their ability to exhibit these complex dynamics.

Can these dynamics be detected in real systems? Schoof and others (2014) observe basal water pressure variations 
with a 2 day repeat time in regions of the bed supplied with diurnally varying meltwater inputs through moulins. Their analysis suggests that this is a manifestation of dynamics similar to the mode locking and resonance we have discussed. This could be investigated further using our model. Other data pertaining to moulin drainage and basal water pressures (e.g. Bartholomaus and others, 2008; Bartholomew and others, 2011; Chandler and others, 2013; Andrews and others, 2014) may contain further evidence of these dynamics that has not yet been detected.

To search for chaotic dynamics in real systems, time series covering many drainage cycles are required. Even the longest existing records of jökulhlaup, moulin and subglacial lake drainage may be insufficient (e.g. Huss and others, 2007; Bartholomew and others, 2011; Kingslake and $\mathrm{Ng}$, 2013b; Siegfried and others, 2014). Moreover, evidence of fine-scale chaotic structure in real time series may be obscured by chaotic weather fluctuations ( $\mathrm{Ng}$ and Liu, 2009). Despite these issues, future analyses of ice-dammed reservoir systems could benefit from an appreciation of these systems' ability to generate complex drainage time series when they behave like forced nonlinear oscillators.

\section{SUMMARY}

We have shown that a model ice-dammed reservoir coupled to a subglacial drainage system can display mode locking, resonance and chaotic dynamics. These dynamics may be important for the long-term evolution and predictability of jökulhlaup systems and could manifest in other ice-dammed reservoir systems such as moulins and subglacial lakes. Understanding jökulhlaups is important for hazard mitigation, and moulins and subglacial lakes are key components in the coupling between hydrology and ice dynamics. These findings suggest that under some circumstances icedammed reservoirs and the glacial systems in which they play a role can undergo abrupt transitions and may be unpredictable in the long term.

\section{ACKNOWLEDGEMENTS}

I acknowledge the support of a University of Sheffield PhD studentship and the British Antarctic Survey (BAS) Polar Science for Planet Earth programme. Thank you to many people including Felix Ng, Alex Robel, Christian Schoof and Mauro Werder for discussions. I also thank Robert Arthern and Richard Hindmarsh for discussions and for commenting on the manuscript. Finally, I thank Helen Fricker and two anonymous reviewers for comments which improved the clarity of the paper.

\section{REFERENCES}

Anderson RS, Walder JS, Anderson SP, Trabant DC and Fountain AG (2005) The dynamic response of Kennicott Glacier, Alaska, USA, to the Hidden Creek Lake outburst flood. Ann. Glaciol., 40, 237-242 (doi: 10.3189/172756405781813438)

Andrews LC and 7 others (2014) Direct observations of evolving subglacial drainage beneath the Greenland Ice Sheet. Nature, 514(7520), 80-83 (doi: 10.1038/nature13796)

Bartholomaus TC, Anderson RS and Anderson SP (2008) Response of glacier basal motion to transient water storage. Nature Geosci., 1, 33-37 (doi: 10.3189/002214311798843269)

Bartholomew I and 6 others (2011) Seasonal variations in Greenland Ice Sheet motion: inland extent and behaviour at higher elevations. Earth Planet. Sci. Lett., 307, 271-278 (doi: 10.1016/j. epsl.2011.04.014)

Bell RE, Studinger M, Shuman CA, Fahnestock MA and Joughin I (2007) Large subglacial lakes in East Antarctica at the onset of fast-flowing ice streams. Nature, 445, 904-907 (doi: 10.1038/ nature05554)

Björnsson H (1992) Jökulhlaups in Iceland: characteristics, prediction and simulation. Ann. Glaciol., 16, 95-106

Björnsson H (1998) Hydrological characteristics of the drainage system beneath a surging glacier. Nature, 395(6704), 771-774 (doi: 10.1038/27384)

Björnsson H (2002) Subglacial lakes and jökulhlaups in Iceland. Global Planet. Change, 35(3), 255-271 (doi: 10.1016/S09218181(02)00130-3)

Björnsson H (2004) Glacial lake outburst floods in mountain environments. In Owens $\mathrm{P}$ and Slaymaker O eds Mountain geomorphology. Edward Arnold, London, 165-184

Carter SP, Fricker HA and Siegfried MR (2013) Evidence of rapid subglacial water piracy under Whillans Ice Stream, West Antarctica. J. Glaciol., 59(218), 1147-1162 (doi: 10.3189/2013JoG13J085)

Chandler DM and 11 others (2013) Evolution of the subglacial drainage system beneath the Greenland Ice Sheet revealed by tracers. Nature Geosci., 6(3), 195-198 (doi: 10.1038/ngeo1737)

Clarke GKC (1982) Glacier outburst floods from Hazard Lake, Yukon Territory, and the problem of flood magnitude prediction. J. Glaciol., 28(98), 3-21

Clarke GKC (2003) Hydraulics of subglacial outburst floods: new insights from the Spring-Hutter formulation. J. Glaciol., 49(165), 299-313 (doi: 10.3189/172756503781830728)

Cowton T and 7 others (2013) Evolution of drainage system morphology at a land-terminating Greenlandic outlet glacier. J. Geophys. Res. Earth Surf., 118, 29-41 (doi: 10.1029/ 2012JF002540)

Das SB and 6 others (2008) Fracture propagation to the base of the Greenland Ice Sheet during supraglacial lake drainage. Science, 320(5877), 778-781 (doi: 10.1038/ngeo1737)

Drazin PG (1992) Nonlinear systems. Cambridge University Press, Cambridge

Evatt GW (2006) Jökulhlaups and subglacial floods. (DPhil thesis, Oxford University)

Evatt GW, Fowler AC, Clark CD and Hulton NRJ (2006) Subglacial floods beneath ice sheets. Proc. R. Soc. London, Ser. A, 364(1844), 1769-1794 (doi: 10.1098/rsta.2006.1798)

Flowers GE, Björnsson H, Pálsson F and Clarke GKC (2004) A coupled sheet-conduit mechanism for jökulhlaup propagation. Geophys. Res. Lett., 31(5), L05401 (doi: 10.1029/ 2003GL019088)

Fowler AC (1999) Breaking the seal at Grimsvötn, Iceland. J. Glaciol., 45(151), 506-516

Fowler AC (2009) Dynamics of subglacial floods. Proc. R. Soc. London, Ser. A, 465(2106), 1809-1828 (doi: 10.1098/ rspa.2008.0488)

Fricker HA and Scambos T (2009) Connected subglacial lake activity on lower Mercer and Whillans Ice Streams, West Antarctica, 2003-2008. J. Glaciol., 55(190), 303-315 (doi: $10.3189 / 002214309788608813$ )

Hewitt and others (2011) Modelling distributed and channelized subglacial drainage: the spacing of channels. J. Glaciol., 57(202), 302-314 (doi: 10.3189/002214311796405951)

Howat IM, Porter C, Noh MJ, Smith BE and Jeong S (2015) Brief communication. Sudden drainage of a subglacial lake beneath the Greenland Ice Sheet. Cryosphere, 9(1), 103-108 (doi: 10.5194/tc-9-103-2015)

Huss M, Bauder A, Werder M, Funk M and Hock R (2007) Glacier-dammed lake outburst events of Gornersee, Switzerland. J. Glaciol., 53(181), 189-200 (doi: 10.3189/ 172756507782202784)

Jóhannesson T (2002) Propagation of a subglacial flood wave during the initiation of a jökulhlaup. Hydrol. Sci. J., 47(3), 417-434 (doi: 10.1080/02626660209492944) 
Kanamaru T (2007) Van der Pol oscillator. Scholarpedia, 2(1), 2202 http://www.scholarpedia.org/article/Van_der_Pol_Oscillator

Kessler MA and Anderson RS (2004) Testing a numerical glacial hydrological model using spring speed-up events and outburst floods. Geophys. Res. Lett., 31(18), L18503 (doi: 10.1029/ 2004GL020622)

Kingslake J (2013) Modelling ice-dammed lake drainage. (PhD thesis, University of Sheffield)

Kingslake J and Ng F (2013a) Modelling the coupling of flood discharge with glacier flow during jökulhlaups. Ann. Glaciol., 54(63), 25-31 (doi: 10.3189/2013AoG63A331)

Kingslake J and Ng F (2013b). Quantifying the predictability of the timing of jökulhlaups from Merzbacher Lake, Kyrgyzstan. J. Glaciol., 59(217), 805-818 (doi: 10.3189/2013JoG12J156)

Magnússon E and 8 others (2011) Localized uplift of Vatnajökull, Iceland: subglacial water accumulation deduced from InSAR and GPS observations. J. Glaciol., 57(203), 475-484 (doi: 10.3189/002214311796905703)

Moon FC and Holmes PJ (1979) A magnetoelastic strange attractor. J. Sound Vib., 65(2), 275-296

Ng FSL (1998) Mathematical modelling of subglacial drainage and erosion. (DPhil thesis, Oxford University)

$\mathrm{Ng} \mathrm{F}$ and Björnsson $\mathrm{H}$ (2003) On the Clague-Mathews relation for jökulhlaups. J. Glaciol., 49(165), 161-172 (doi: 10.3189/ 172756503781830836)

Ng F and Liu S (2009) Temporal dynamics of a jökulhlaup system. J. Glaciol., 55(192), 651-665 (doi: 10.3189/ 002214309789470897)

Ng F, Liu S, Mavlyudov B and Wang Y (2007) Climatic control on the peak discharge of glacier outburst floods. Geophys. Res. Lett., 34(21), L21503 (doi: 10.1029/2007GL031426)

Nienow P, Sharp M and Willis I (1998) Seasonal changes in the morphology of the subglacial drainage system, Haut Glacier d'Arolla, Switzerland. Earth Surf. Process. Landf., 23(9), 825-843 (doi: 10.1002/(SICl)1096-9837(199809) 23:93.0.CO;2-2)

Novak S and Frehlich RG (1982) Transition to chaos in the Duffing oscillator. Phys. Rev. A, 26(6), 3660 (doi: 10.1103/PhysRevA.26.3660)

Nye J (1976) Water flow in glaciers: jökulhlaups, tunnels and veins. J. Glaciol., 17(76), 181-207

Ott E (2002) Chaos in dynamical systems. Cambridge University Press, Cambridge

Pimentel S and Flowers GE (2011) A numerical study of hydrologically driven glacier dynamics and subglacial flooding.
Proc. R. Soc. London, Ser. A, 467(2126), 537-558 (doi: 10.1098/rspa.2010.0211)

Roberts MJ (2005) Jökulhlaups: a reassessment of floodwater flow through glaciers. Rev. Geophys., 43, RG1002 (doi: 10.1029/ 2003RG000147)

Schoof C, Rada CA, Wilson NJ, Flowers GE and Haseloff M (2014) Oscillatory subglacial drainage in the absence of surface melt. Cryosphere, 8(3), 959-976 (doi: 10.5194/tc-8-959-2014)

Sergienko OV (2013) Glaciological twins: basally controlled subglacial and supraglacial lakes. J. Glaciol., 59(213), 3-8 (doi: 10.3189/2013JoG12J040)

Shen Y, Wang G, Shao C, Mao W and Wang S (2007) Response of glacier flash flood to climate warming in the Tarim River Basin. Adv. Climate Change Res., 3, 51-56

Siegfried MR, Fricker HA, Roberts M, Scambos TA and Tulaczyk S (2014) A decade of West Antarctic subglacial lake interactions from combined ICESat and CryoSat-2 altimetry. Geophys. Res. Lett., 41, 891-898 (doi: 10.1002/2013GL058616)

Spring U and Hutter K (1981) Numerical-studies of jökulhlaups. Cold Reg. Sci. Technol., 4(3), 227-244 (doi: 10.1016/0165232X(81)90006-9)

Stearns and others (2008) Increased flow speed on a large East Antarctic outlet glacier caused by subglacial floods. Nature Geosci., 1(12), 827-831 (doi: 10.1038/ngeo356)

Sugiyama S, Bauder A, Weiss P and Funk M (2007) Reversal of ice motion during the outburst of a glacier-dammed lake on Gornergletscher, Switzerland. J. Glaciol., 53(181), 172-180 (doi: 10.3189/172756507782202847)

Werder MA and Joughin IR (2013) Fast flow of Jakobshavn Isbræ and its subglacial drainage system. Am. Geophys. Union, Fall Meet., Abstr. C33B-0716

Werder MA, Hewitt IJ, Schoof CG and Flowers GE (2013) Modeling channelized and distributed subglacial drainage in two dimensions. J. Geophys. Res., 118(4), 2140-2158 (doi: 10.1002/ jgrf.20146)

Wingham DJ, Siegert MJ, Shepherd A and Muir AS (2006) Rapid discharge connects Antarctic subglacial lakes. Nature, 440(7087), 1033-1036 (doi: 10.1038/nature04660)

Wright A and Siegert M (2012) A fourth inventory of Antarctic subglacial lakes. Antarct. Sci., 24(6), 659-664 (doi: 10.1017/ S095410201200048X)

Zwally HJ, Abdalati W, Herring T, Larson K, Saba J and Steffen K (2002) Surface melt-induced acceleration of Greenland icesheet flow. Science, 297(5579), 218-222 (doi: 10.1126/ science.1072708) 